\title{
TEACHING READING COMPREHENSION BY USING PREDICT, LOCATE, ADD NOTE STRATEGY TO THE EIGHTH GRADE STUDENTS OF SMP NEGERI 2 LUBUKLINGGAU
}

\author{
Maria Ramasari ${ }^{1)}$ Cintia Novtarina ${ }^{2)}$ \\ ${ }^{1}$ STKIP PGRI Lubuklinggau \\ email: mariaramasari@gmail.com \\ ${ }^{2}$ STKIP PGRI Lubuklinggau \\ email: cintianovtarina@gmail.com
}

\begin{abstract}
The purpose of this research was to find out whether or not it is significantly effective to teach reading comprehension by using Predict, Locate, Add Note strategy to the Eighth Grade Students of SMP Negeri 2 Lubuklinggau in the academic year of 2016/2017. The researcher used pre experimental method with one group pre-test and post-test design. The population was all the eighth grade students of SMP Negeri 2 Lubuklinggau which consisted of 440 students. The sample was taken through cluster random sampling. The sample was 40 students. The data was collected through test consisted of 20 items of multiple choices. The data were analyzed through four techniques: 1) students' individual score, 2) minimum mastery criteria, 3) normality, and 4) matched t-test calculation. The result of this research: (1) the mean students' score in the pre-test was 62.3, (2) The mean score of post-test was 77.3, and (3) the result of Matched t-test was 10.86, which was higher than 1.684 value of the $t$-table of 39 (40-1) with $95 \%$ significant level for one tailed-test. Therefore, null hypothesis (Ho) was rejected and the alternative hypothesis (Ha) was accepted. It means that it was significantly effective to teach reading comprehension by using Predict, Locate, Add Note Strategy to the eighth grade students of SMP Negeri 2 Lubuklinggau in academic year of 2016/2017.
\end{abstract}

Keywords: teaching, reading, Predict, Locate, Add Note strategy 


\section{INTRODUCTION}

Language becomes a media to be used as human communication. In building communication, people make efforts to convey and obtain the various informations needed in their daily life. Language is a fundamental part of human being (Haliwel, 1992:11). In addition, language is a complex, specialize skill which develops in the child spontaneously without conscious effort or formal instruction (Brown, 2001:7). Therefore, language is very important thing for people. From many kinds of language used by most of people all over the world, English is one of international language that is claimed to be learned as lingua franca including in Indonesia which learned English as Foreign Language.

Moreover, Brown (2001:232) views that in English language teaching, English can be identifies into four skills, listening, speaking, reading and writing. Reading is an essential skill among them because reading activities is dominant in classroom. Sweet (2000:5) states that reading comprehends, that is the construction of meaning. By reading, students will have much knowledge and information. The purpose of teaching reading is to improve students' skill in comprehending the text and getting important information contained in the text. Teaching reading is an important part of the teachers' job. Teacher has important role in teaching reading in order students can comprehend the text. When the students are not taught how to read by teacher, thus students are not able to achieve the goal of teaching reading. If the students can understand about the text, they can call comprehension.
As Harmer's opinion (2003:68) teaching reading is teachers' job in the class.

In addition, the researcher did an interview with the English teacher of SMP Negeri 2 Lubuklinggau, she got some information of the students' problem in reading: (1) the students had lack of vocabulary; students could not interpret the meaning of many words in a text because had limited on vocabulary knowledge or individual stock; (2) the students had lack motivation in reading. It meant that they had difficulty to understand the main idea of the text that they have read. It could be caused by internal factors and external factors. Motivation and intelligence are the examples of internal factors. Meanwhile, economic background, learning materials and teachers' performance including their teaching methods are the examples of external factors. The students were not interested to read and got difficulties to comprehend the reading text; and (3) the students were not consistent to practice of the reading text. The information are the problems faced by students. In line with phenomenon described, teaching reading is not easy. To solve the problems, the researcher introduced a strategy in order to help the students easier to learn and overcome their difficulties in comprehending a reading material. It is Predict, Locate, Add Note strategy.

According to Barton, Lee and Deborah (2001:96), the application of Predict, Locate, Add Note strategy for Junior High School gives good effect to the students' reading comprehension. They were more enjoyable in learning reading and comprehend the text easily. Predict, Locate, Add Note strategy is a comprehension strategy for informational 
text that helps students read strategically that builds students' prior knowledge before they read a text, during reading, and after reading by listening the teacher's short lecture, reading a text selection, and discussing (Caverly, 1995:190). Therefore, the researcher was extremely interested to conduct a research entitled: "Teaching Reading Comprehension through Predict, Locate, Add Note (P.L.A.N) Strategy to the Eighth Grade Students of SMP Negeri 2 Lubuklinggau".

\section{METHOD}

The researcher used a preexperimental with one group pre test and post-test design. According to Fraenkel and Wallen (1993:231), in one group pre-test and post-test design, a single group is measured or observed not only after being expose to a treatment of some sort, but also before. The cluster random sampling is one of the techniques to choose a sample from the population. It is one of sample by randomizing of group the sample and it is a sample composed of groups rather than individuals (Fraenkel and Wallen, 1993:97). Cluster random sampling was done by writing the name of eleven classes from the eighth grade students of SMP Negeri 2 Lubuklinggau in the eleven small pieces of papers; furthermore the researcher mixed them in the glass. Finally, the researcher took one of them. The result was the VIII.6 class that consisted 40 students as the class was chosen as the sample of this research.

\section{FINDINGS AND DISCUSSION}

This part described the result of the test distributed to the sample students before and after treatment. There were five finding in the investigation: they were (1) the students' scores in the pre-test, (2) the students' scores post-test,(3) the comparison students' score in pre-test and post-test, (4) normality testing, (5) the result of matched t-test calculation. Based on the data analysis, the result in the pretest showed that the mean score in the pretest was 65.3 and in post-test was 77.8. It means that the average score in post-test was higher than the students' average score in the pre-test. In addition, the researcher also found the result of the matched t-test calculation was 10.86 meanwhile the t-table was 1.684. It means that the $\mathrm{Ha}$ was accepted and Ho was rejected. So, it can be said that Predict, Locate, Add Note strategy was effective to be used in reading comprehension to the eighth grade students of SMP Negeri 2 Lubuklinggau in academic year of 2016/2017.

\subsection{The Students' Score in Pre-test}

The pre-test was given before the treatment. The pre-test consisted of 25 items in the form of multiple choices about reading comprehension of recount text that have been done in 45 minutes. The number of the students who took in the pre-test was 40 students. After the scores had been tabulated, based on the students qualification, the researcher found out that the highest score was 80 which achieved by 4 students, and the lowest score was 40 which was reached by 2 students. The average of students score in the pre-test was 65.3. It means that the students' 
average ability was in the "Failed" criteria. The Score range of the students' score in the pre-test (appendix C) is showed in the chart below:

\section{Chart 3.1.1}

The Students' Categories in the Pre-Test

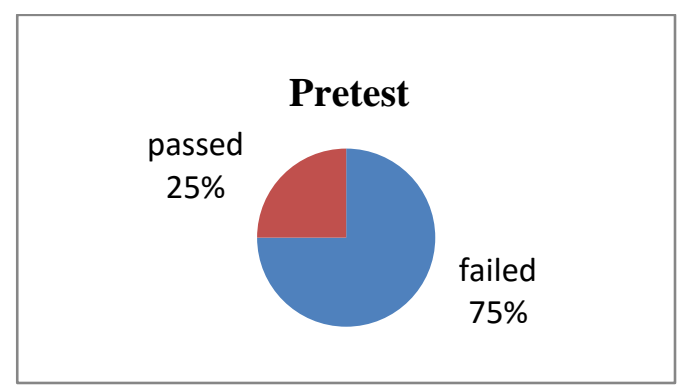

The chart above showed that there were 30 students or $75 \%$ who were in "Failed" criteria and there were 10 students or $25 \%$, who were in "Passed" criteria. In other words, the number of students that still need to be improved was quite high. Therefore, the researcher gave the treatments to the students' that was teaching reading by using Predict, Locate, Add Note Strategy.

\subsection{The Students' Score in the Post-test}

The post-test was given after treatment. The number of the students who were given post-test was 40 students. The test which was given to the students was same with the pre-test, the researcher gave 25 items of test in multiple choice from about reading comprehension of recount text that have been done in 45 minutes. The score was obtained by dividing the total number of individual score by the total number of the students 40 that was 3112: $40=77.8$. After the researcher analysis the post-test, it was found that the highest score was 92 reached by 3 students and the lowest score was 48 reached by 1 student.
After the score had been tabulated, based on the Minimum Mastery Criteria (MMC) the researcher found that was 9 students who were in the "Failed". And there were 31 students who were in "Passed" criteria. The average of the students' score in the post-test was 77.8. This indicated that there was progress in the students reading comprehension Mastery, from 40 students who had mastered to 31 students and average from 65.3 to 77.8 . Based on the students' score in the converted into the students Minimum Mastery Criteria the students' score increase. Score range of the students' score in the post-test (see appendix C) is showed in the chart below:

\section{Chart 4.2}

The Students' Categories in the PostTest

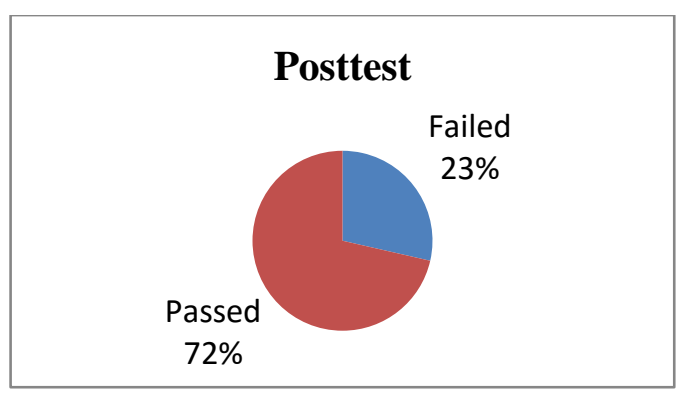

The chart above show that the students who were in the "Failed" criteria was score 9 students or $23 \%$, and there were 31 students or $72 \%$ who were in "Passed" criteria, it was meant that the material was mastered for the students. 


\begin{tabular}{|l|l|l|l|l|l|l|l|}
\hline \multirow{2}{*}{ No } & \multirow{2}{*}{ Categories } & \multicolumn{6}{|c|}{ The Recapitulation of Pre-test and Post-test Score } \\
\cline { 3 - 8 } & & $\begin{array}{l}\text { Mean } \\
\text { score }\end{array}$ & $\begin{array}{l}\text { Total } \\
\text { score }\end{array}$ & $\begin{array}{l}\text { Highest } \\
\text { score }\end{array}$ & $\begin{array}{l}\text { Lowest } \\
\text { score }\end{array}$ & $\begin{array}{l}\text { Passed } \\
\text { criteria }\end{array}$ & $\begin{array}{l}\text { Failed } \\
\text { criteria }\end{array}$ \\
\hline 1. & Pre-test & 65.3 & 2612 & 80 & 40 & 10 & 30 \\
\hline 2. & Post-test & 77.8 & 3112 & 92 & 48 & 31 & 9 \\
\hline
\end{tabular}

\subsection{The Comparison between the Result of the Pre-test and Post-test}

In order to show the difference of the students' score between the pre-test and post-test, the researcher presented the detailed scores in the table. This table 4.1 also helps the researcher to differ the students who obtained the worse scores and the better scores in the reading test. Moreover, it can be used to interpret whether or not the treatment was effective to help the students improve their reading achievement. The comparison of the students' score in the pre and post test could be seen in the following table 3.3.1:

\subsection{Normality Testing}

Normality testing was proposed to saw was the data of the result of the test was distributed normal or not. Based on the criteria normality testing of the statistical calculation (in appendix C) about normality testing of data with degree of freedom $\alpha=$ 0.05 if $\chi^{2}$ obtained $<\chi^{2}$ table, so it can be concluded the data distribution in the test was normal. The result of normality testing of pre-test and post-test could be seen in the table 3.4.1 below:
Table 3.4.1

\begin{tabular}{|l|l|l|l|l|l|}
\hline $\begin{array}{l}\text { N } \\
\text { o }\end{array}$ & $\begin{array}{l}\text { Clas } \\
\text { S } \\
\text { (VIII } \\
.1)\end{array}$ & $\begin{array}{l}c^{2}{ }_{\text {obta }} \\
\text { ined }\end{array}$ & $\begin{array}{l}\text { D } \\
\text { F }\end{array}$ & $\begin{array}{l}\chi_{\text {ta }} \\
\text { ble }\end{array}$ & $\begin{array}{l}\text { Conclu } \\
\text { sion }\end{array}$ \\
\hline 1. & $\begin{array}{l}\text { Pre- } \\
\text { test }\end{array}$ & 8.47 & 5 & $\begin{array}{l}11 \\
.1\end{array}$ & Normal \\
\hline 2. & $\begin{array}{l}\text { Post- } \\
\text { test }\end{array}$ & 8.66 & 5 & $\begin{array}{l}11 \\
.1\end{array}$ & Normal \\
\hline
\end{tabular}

From the table 4.2 could be known that in pre-test and post-test the $C_{\text {obtained }}^{2}$
The result of the Normality testing in pre-test and post-test

was less than $\chi_{\text {table }}^{2}$ So, it can be concluded $C^{2}$ (chi square) in the pre-test and post-test was distributed normal with $\alpha=0.05$ and degree of freedom $(\mathrm{df})=5(6-1)$.

\subsection{The Result of Matched t-test Calculation}

In analyzing the data the researcher used the matched t-test to find out whether or not to teach reading comprehension through listen-read-discuss strategy to the eighth grade students of SMP Negeri 2 Lubuklinggau in the academic year of 
2016/2017. Based on the appendix C, it was found that the number of the students (N) is 40, SD (Standard Deviation) was 0.68 . The result matched t-test calculation was 16.91 , meanwhile the critical value in the table was 1.684 and the degree of freedom (df) was 39 (40-1) with the significance level $95 \%$ for one tailed. It meant that $t_{\text {obtained }}$ was higher than $t_{\text {table }}$. The $t_{\text {obtained }}$ (10.86) indicated that the alternative hypothesis (Ha) was accepted and the null hypothesis was rejected because t-obtained $>$ t-table. From the explanation above, it can be stated that it was effective to improve in teaching reading comprehension by using Predict, Locate, Add Note strategy to the eighth grade students of SMP Negeri 2 Lubuklinggau in the academic years of 2016/2017.

The researcher interpreted the result of data analysis. The result of the pre-test and post-test showed that there was a significantly different between the students' score before and after the treatments. Based on the test, before treatment the students' average score in the pre-test was 65.3. The highest score was 80 , achievement by three students and lowest score was 40 achieved by two students. The students' average score it can be interpreted that their ability in the reading comprehension was in categorized of "failed" qualification. Before the students got the treatments, the researcher found that there were 30 students who were in "failed" criteria. Moreover, there were 10 students who were in "passed" criteria. It means that almost all students still have some problems and weaknesses in their reading such as, the students can read and understand the reading text, but they were difficult to represent main ideas and the author's message in their own words. Some students are not able to get specific information in each reading text. Therefore, when they were asked to identify between specific information and general information, the students could not difference those text appropriately. The last problem was the students had limited vocabulary. Therefore, the students should learn some have many words and memorized the words that suited to the context. In other words, it was impossible to comprehend a text without knowing the meaning and understanding of what the words refer to the recount text. All the problems could be seen from the result of pre-test in appendix $\mathrm{C}$.

The researcher administered the post-test, The mean score in the post-test was 77.8 whereas, the highest score was 92 by three students, and lowest score was 48 achieved by one student. It can be interpreted that their ability got improvement. It means that there was any increasing in their average score, where the students' score in the post-test was higher than in the pre-test. It could be interpreted that the treatment by using Predict, Locate, Add Note strategy can help the students increase their reading comprehension, especially in reading recount text.In addition, the researcher got the result matched t-test calculation that the $t_{\text {obtained }}(10.86)$ was completely higher that $t_{\text {table }}(1.684)$, it could be known that the null hypothesis (Ho) was rejected and the alternative hypothesis was accepted. Predict, Locate, Add Note strategy was effective in teaching reading comprehension to the eighth grade students of SMP Negeri 2 Lubuklinggau in the academic year of 2016/2017. 
A better improvement on the posttest was influenced by using Predict, Locate, Add Note strategy that helped students to comprehend the text. Students interacted more with the text as they created their predictions into a map. Then, it engaged students' background knowledge of the topic that simultaneously built their interest and motivation to read. It also helped students to recognize text construction easily. In addition, the researcher got the result matched t-test calculation that the $t_{\text {obtained }}$ (10.86) was completely higher that $t_{\text {table }}(1.684)$, it could be known that the null hypothesis (Ho) was rejected and the alternative hypothesis was accepted. Predict, Locate, Add Note strategy was effective in teaching reading comprehension to the eighth grade students of SMP Negeri 2 Lubuklinggau in the academic year of 2016/2017.

\section{CONCLUSION}

Based on the result of the research researcher concludes that it was significantly effective to teach reading comprehension by using Predict, Locate, Add Note strategy to the Eighth Grade Students of SMP Negeri 2 Lubuklinggau in the academic year of 2016/2017?" It could be proved by the result of the test and the differences between the two means of score in the pre-test and in the post-test which was calculated by using matched ttest formula. According to this analysis, and described earlier the researcher found that the alternative hypothesis (Ha) was accepted and the null hypothesis (Ho) was rejected. Since the result of the calculation of matched t-test was higher than the critical value. It could be checked through the significant different between the two average scores in the pre-test (65.3) and also the post-test (77.8), these were tested through the matched t-test. The result of Matched t-test was 10.48 which was higher than 1.684 value of the $t_{-}$table of 39 (40-1) with $95 \%$ significant level for one tailed-test. Therefore, null hypothesis (Ho) was rejected and the alternative hypothesis (Ha) was accepted. It means that the researcher concluded that it was effective in teaching reading comprehension by using Predict, Locate, Add Note strategy to the eighth grade students of SMP Negeri 2 Lubuklinggau in the academic years of 2016/2017.

\section{REFERENCES}

Barton, M, L., \& Deborah, L. (2001). Teaching Reading in Science : A Supplement to Teaching Reading in the Content Areas Teacher's Manual $\left(2^{\text {nd }} e d.\right)$. Alexandria : McREL.

Brown, H. D. (2001). Principles of Language Learning and Teaching. New York: Pearson Education: Pearson Education

Caverly, T .(1995). PLAN: A Study Reading Strategy for Informational Texts. Journal of Adolescent and Adult Literacy. Retrieved from http://www.jstor.org/stable/40015 675

Fraenkle, J. R., \& Wallen, N.E. (1993). How to Design and Evaluate Research. New York, NY: McGraw-Hill, Inc.

Haliwel, S. (1992). Longman Handbooks For Language Teachers Teaching 
English In The Primary Classroom. New York: Longman

Harmer, Jeremy. (2003). How to Teach English: An Introducing to the Practice of English

LanguageTeaching. England:
Addison Wesley Longman Limited

Sweet, A. P. (2000). Ten Proven Principles for teaching Reading. U.S. Department of Education. 